Terbit online pada laman web jurnal : http://teknosi.fti.unand.ac.id/

\title{
Implementasi Load Balancing Web Server menggunakan Haproxy dan Sinkronisasi File pada Sistem Informasi Akademik Universitas Siliwangi
}

\author{
Alam Rahmatulloh ${ }^{1}$, Firmansyah MSN \\ Universitas Siliwangi, Jalan Siliwangi No.24, Tasikmalaya, 46115, Indonesia
}

\begin{tabular}{l} 
INFORMASI ARTIKEL \\
\hline Sejarah Artikel: \\
Diterima Redaksi: 15 Juli 2017 \\
Revisi Akhir: 17 Agustus 2017 \\
Diterbitkan Online: 31 Agustus 2017 \\
KATA KUNCI \\
\hline web server \\
Load Balancing \\
Server Clustering \\
Sistem Informasi Akademik \\
Sinkronisasi File \\
KoRESPONDENSI \\
\hline
\end{tabular}

Telepon: +62 85223519009

E-mail: alam@unsil.ac.id

\section{PENDAHULUAN}

Ketersediaan infrastruktur teknologi informasi yang kuat (strong) dan handal (reliable) merupakan permasalahan yang dihadapi oleh perusahaan atau instansi yang mengelola ribuan bahkan jutaan data setiap harinya. Salah satu infrastruktur yang digunakan dalam mengelola data-data tersebut adalah server [1]. Server merupakan sistem komputer yang menyediakan layananlayanan tertentu seperti sistem operasi, program aplikasi maupun data-data informasi kepada komputer lain yang saling terhubung dalam sebuah jaringan komputer. Mengingat fungsi yang dimiliki server adalah memberikan layanan kepada client, maka server dituntut untuk bisa melayani permintaan (request) dari semua client.

UPT TIK sebagai pelaksana teknis pengelola Sistem Informasi Akademik (SIMAK) Universitas Siliwangi memiliki server sebagai penyedia layanan informasi yang bergantung pada satu

https://doi.org/10.25077/TEKNOSI.v3i2.2017.241-248

\section{A B S T R A K}

Saat ini Universitas Siliwangi memiliki populasi pengguna Sistem Informasi Akademik sebesar 12829 orang yang terdiri dari mahasiswa, karyawan dan dosen. Dengan arsitektur server tunggal saat ini, sering terjadi overload jika banyak request user secara bersamaan seperti pada kegiatan pengisian kartu rencana studi mahasiswa. Hal ini menimbulkan kondisi server down karena matinya aplikasi web server dan database server sehingga banyak user yang dak dapat dilayani dengan kondisi server tunggal. Arsitektur multi server memanfaatkan load balancing web server merupakan salah satu solusi presuest pada Sistem Informasi Akademik dibagi secara merata ke berapa server. Hasil penelitian yang didapatkan yaitu load balancing dapat rja dengan baik ketika request datang dari client telah berhasil ( request dengan tidak mengalami error request. Selain itu, penerapan kronisasi file bekerja dengan baik dimana file yang diupload pada node 1 akan disinkron ke setiap node 2 dan node 3 pada cluster, begitu juga sebaliknya karena sinkronisasi file ini bersifat dua arah.

server. Karena banyaknya permintaan (request) terhadap server SIMAK, maka server tersebut mengalami kelebihan kapasitas (overload), keadaan tersebut diketahui dari hasil pengamatan pada waktu registrasi dan pengisian KRS online. Dimana request pada server SIMAK secara bersamaan (Current Connection) bisa mencapai 199 request. Sedangkan kemampuan server hanya dapat menangani hingga 70 request, hasil tersebut didapat dari perhitungan jumlah memory server dikurangi jumlah memory yang terpakai untuk operating sistem dan services mysql dibagi jumlah memory rata - rata yang digunakan setiap proses web server [2]. Solusi yang dapat dilakukan untuk meningkatkan kemampuan server dalam melayani permintaan (request) yaitu dengan mengupgrade hardware server. Solusi tersebut masih terdapat kekurangan, karena sebuah server memiliki batasan hardware yang bisa terpasang pada satu server.

Solusi lain yang dapat dilakukan untuk memenuhi permintaan dari client dengan menambah unit server baru dan menerapkan metode clustering [3], dimana beberapa server melayani 
permintaan client secar merata sehinga jumlah current connection bisa meningkat dan ketersediaan server lebih tinggi. Cluster adalah sekelompok mesin yang bertindak sebagai sebuah entitas tunggal untuk menyediakan sumber daya dan layanan ke jaringan [4]. Pada metode clustering server ini terdapat dua fungsi yaitu sebagai failover cluster dan load balancing cluster. Fungsi failover bekerja ketika salah satu server bagian dari cluster (node) mengalami kerusakan maka akan digantikan oleh server yang lain, sehingga layanan tidak mengalami gangguan. Sedangkan fungsi load balancing cluster bekerja ketika server menangani permintaan, semua permintaan akan dibagi secara merata ke semua node pada cluster sehingga server tidak akan mengalami kelebihan kapasitas (overload).

Pada penelitian sebelumnya, yang sudah dilakukan diantaranya oleh Maya Rosalia dkk (2016) [5] dan Sirajuddin dkk (2012) [6] hanya melakukan penerapan load balancing pada server virtual sehingga hasil yang diujikan hanya bergantung pada kekuatan server yang dijadikan media virtual. Kendala lain yang akan muncul ketika menerapkan metode clustering yaitu munculnya missing file, karena setiap client akan mengakses node server yang berbeda setiap kali mereka melakukan request pada server cluster. Untuk mengatasi permasalahan-permasalah pada penelitian sebelumnya, maka selain load balancing perlu metode file sinkronisasi yang akan bekerja ketika client melakukan upload data pada node tertentu dan di sinkron ke semua node pada cluster. Sehingga ketika client melakukan request kembali dan dilayani oleh node yang berbeda, maka data yang telah diupload akan tersedia.

\section{TINJAUAN PUSTAKA}

\subsection{Jaringan Komputer}

Jaringan Komputer adalah suatu sistem telekomunikasi yang didalamnya terdiri dari dua atau lebih perangkat komputer yang dirancang untuk dapat berkerja secara bersama-sama dengan tujuan dapat berkomunikasi, mengakses informasi, meminta serta memberikan layanan atau service antara komputer satu dengan yang lainnya [7].

Jaringan komputer pada umum nya di kelompokkan menjadi 5 kategori, yaitu berdasarkan jangkauan geografis, media tranmisi data, distribusi sumber informasi/data, peranan dan hubungan tiap komputer dapam memproses data, dan berdasarkan jenis topologi yang digunakan. Jenis jaringan komputer berdasarkan jangkauan geografis yaitu:

1. Local Area Network : Local area network atau disingkat LAN merupakan jaringan yang mencakup wilayah kecil. salah satu contoh adalah jaringan komputer yang berada dilingkup sekolah, kampus atau kantor. Biasanya jaringan LAN menggunakan teknologi IEEE 802.3 ethernet dengan kecepatan transfer data sekitar $10 \mathrm{MB} / \mathrm{s}, 100 \mathrm{MB} / \mathrm{p}$ dan 1 $\mathrm{GB} / \mathrm{s}$. selain menggunakan teknologi ethernet jaringan LAN bisa menggunakan teknologi nirkabel seperti wi-fi.

2. Metropolitan Area Network : Metropolitan area network atau disingkat WAN merupakan sebuah jaringan yang berada di dalam satu kota dengan kecepatan transfer data tinggi yang menghubungkan beberapa tempat tetapi masih dalam satu wilayah kota. jaringan MAN merupakan gabungan dari beberapa jaringan LAN

3. Wide Area Network : Wide area network atau disingkat WAN merupakan jaringan yang jangkauannya mencakup daerah geografis yang luas, semisal antar wilayah, daerah, kota, negara bahkan benua.

\subsection{Web Server}

Web server adalah sebuah software yang memberikan layanan berbasis data dengan menggunakan protokol HTTP atau HTTPS dari client menggunkan aplikasi web browser untuk request data dan server akan mengirim data dalam bentuk halaman web dan pada umumnya berbentuk dokumen HTML. Halaman web yang diminta bisa terdiri dari berkas teks, video, gambar, file dan banyak lagi.

Salah satu program dari Web Server adalah Apache [8]. Apache merupakan web server yang paling banyak dipergunakan di Internet. Program ini pertama kali didesain untuk sistem operasi lingkungan UNIX, untuk saat ini telah tersedia apache yang di desai untuk sistem operasi lainnya. Apache mempunyai program pendukung yang cukup banyak. Hal ini memberikan layanan yang cukup lengkap bagi penggunanya.

Aplikasi lain yang memiliki fungsi sebagai web server diantaranya, apache Tomcat, Microsoft windows Server 2003 Internet Information Services (IIS), Lighttpd, Sun Java System Web Server, Xitami Web Server, dan Zeus Web Server Arsitektur request dan response web server dapat dilihat pada gambar 1 .

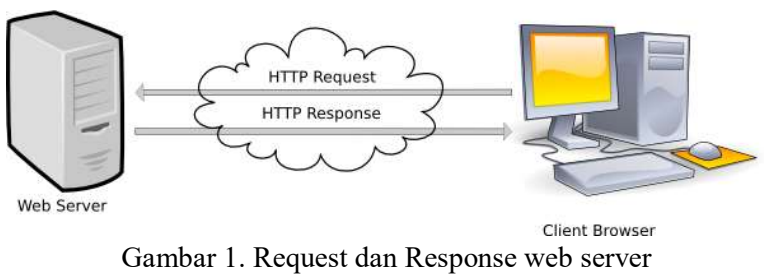

\subsection{Load Balancing}

Load balancing adalah teknik untuk mendistribusikan beban trafik pada dua atau lebih jalur koneksi secara seimbang, agar trafik dapat berjalan optimal, memaksimalkan throughput, memperkecil waktu tanggap dan menghindari overload pada salah satu jalur koneksi [9] [10]. Load balancing digunakan pada saat sebuah server telah memiliki jumlah user yang telah melebihi maksimal kapasitasnya. Load balancing juga mendistribusikan beban kerja secara merata di dua atau lebih komputer, link jaringan, CPU, hard drive, atau sumber daya lainnya, untuk mendapatkan pemanfaatan sumber daya yang optimal. Salah satu teknik load balancing adalah HaProxy [11]. Topologi Load Balancing dapat dilihat pada gambar 2. 


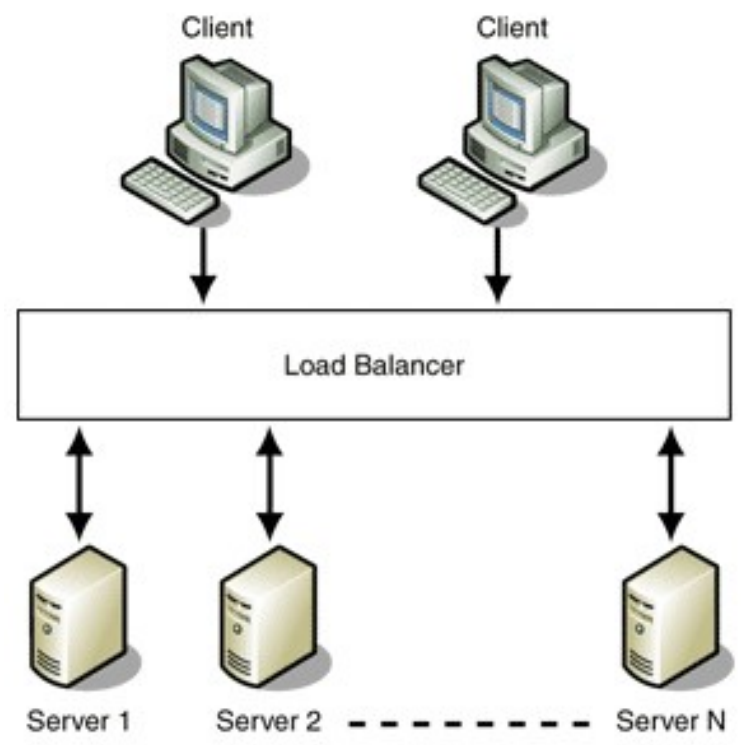

Gambar 2. Konfigurasi Arsitektur Load Balance

\subsection{Database Server}

Database server adalah aplikasi komputer yang menyediakan layanan data ke komputer atau program komputer dan memiliki fungsi sebagai tempat penyimpanan data, seperti yang ditetapkan oleh model klien-server. Istilah ini juga merujuk kepada sebuah komputer yang didedikasikan untuk menjalankan program server database. Salah satu contoh aplikasi database adalah MySQL, Oracle, MariaDB dan lain sebagainya.

\section{METODOLOGI}

Penelitian dilakukan dengan metode PPDIOO (Prepare, Plan, Design, Implement, Operate, Optimize) yang merupakan standar pengembangan siklus hidup pengelolaan jaringan yang diinisiasi oleh Cisco [12]. Pada metode ini cisco membagi fase pengembangan jaringan menjadi enam fase: Prepare (persiapan), Plan (Perencanaan), Design (Desain), Implement (Inplementasi), Operate (Operasi) dan Optimize (Optimasi). Alur PPDIOO dapat dilihat pada gambar 3 .

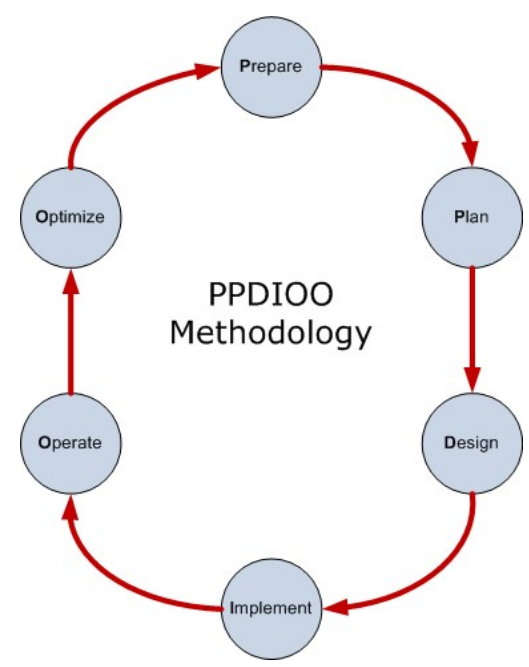

Gambar 3. PPDIOO Methodology [13]
Fase Prepare (persiapan) menetapkan kebutuhan organisasi, mengembangkan strategi jaringan, dan mengusulkan konsep arsitektur dengan level tingkat tinggi, untuk mendukung suatu strategi, yang didukung dengan kemampan keuangan pada organisasi atau perusahaan tersebut.

Fase Plan (perencanaan) mengidentifikasi persyaratan jaringan berdasarkan tujuan, fasilitas, dan kebutuhan pengguna. Fase ini mendeskripsikan karakteristik suatu jaringan, yang bertujuan untuk menilai jaringan tersebut. Melakukan analisis pada perancangan terbaik sebuah arsitektur, dengan melihat perilaku dari lingkungan operasional. Sebuah perencanaan proyek dikembangkan untuk mengelola tugas - tugas (tasks), pihak pihak yang bertanggung jawab dan semua sumber daya untuk melakukan desain dan implementasi. Berdasarkan permasalahan yang dikemukakan pada fase prepare, maka perlu dilakukan penerapan clustering pada server aplikasi untuk dapat menangani permintaan dari pengguna yang terus meningkat. Untuk melakukan implementasi clustering server pada server sistem akademik Universitas Siliwangi dibutuhkan 5 server baru. Server pertama difungsikan sebagai Balancer, server kedua sampai keempat difungsikan sebagai Node Cluster dan server kelima sebagai database server. Kemudian untuk server lama kami rekomendasikan untuk dijadikan server web untuk website fakultas dan jurusan.

Fase Desain, Desain jaringan dikembangkan berdasarkan persyaratan teknis, dan bisnis yang diperoleh dari kondisi sebelumnya. Spesifikasi desain jaringan adalah desain yang bersifat komprehensif dan terperinci, yang memenuhi persyaratan teknis dan bisnis saat ini. Jaringan tersebut haruslah menyediakan ketersediaan, kehandalan, skalabilitas dan kinerja.

Pada fase implement, dilakukan instalasi dan konfigurasi, sesuai spesifikasi desain. Perangkat-perangkat ini akan mengganti infrastruktur yang ada. Perubahan kebutuhan juga harus diikuti selama fase ini, jika ada perubahan seharusnya disampaikan dalam pertemuan (meeting), dengan persetujuan yang diperlukan untuk dilanjutkan.

Fase Optimalisasi, melibatkan kesadaran proaktif seorang manajemen jaringan dengan mengindentifikasi dan menyelesaaikan masalah, sebelum persoalan tersebut mempengaruhi jaringan. Fase optimalisasi, memungkinkan untuk memodifikasi desain jaringan, jika terlalu banyak masalah jaringan yang timbul, kemudian juga untuk memperbaiki masalah kinerja, atau untuk menyelesaikan masalah-masalah pada aplikasi (software).

\section{HASIL DAN PEMBAHASAN}

\subsection{Perancangan Konfigurasi}

Perancangan server clustering yang akan dibangun untuk web server load balancing dengan apache yaitu menggunakan satu server sebagai server gateway load balancing, tiga server sebagai web server utama dan satu server sebagai database. Server gateway berfungsi untuk mengatur pembagian beban antar web server utama dapat seimbang dan ketiga server terhubung menjadi sebuah sistem web server clustering. Desain atau perancangan server clustering dapat dilihat pada Gambar 10. 


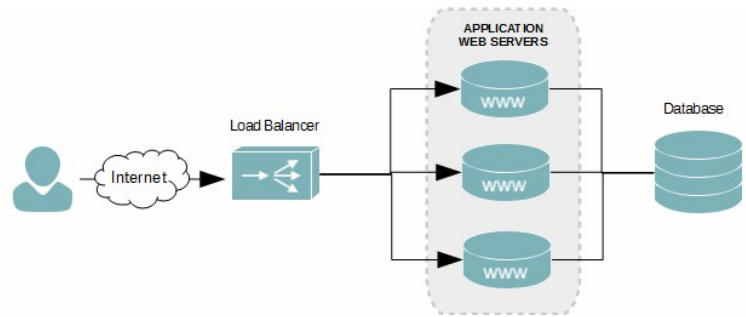

Gambar 4. Rancangan Server Clustering.

Gambar 4 merupakan desain arsitektur server clustering menggunakan apache. Satu server yang terinstal HAProxy sebagai gateway load balancing bertugas membagi beban request dari user kepada tiga server utama. Server utama terinstal apache sebagai web server dan UNISON sebagai aplikasi sinkronisasi master to master dari folder di 3 server utama yang menjadi tempat upload file dari user seperti foto. 3 server utama terhubung ke 1 server database yang menggunakan aplikasi maria DB. Untuk keamanan 3 server utama dan 1 server database diatur di router tidak bisa diakses secara langsung dari internet dan jaringan LAN, hanya ip tertentu dari jaringan tertentu yang bisa mengaksesnya. Pengkabelan dari arsitektur yang dirancang dapat dilihat pada Gambar 12 dengan spesifikasi configurasi sebagai berikut:

a. Router

- $\quad$ Eth $1: 202.52 .13 .161$ (IP dari ISP)

- $\quad$ Eth 2 : Bridge ke LAN 1 (Ke server Load Balancing)

- $\quad$ Eth $3: 10.10 .10 .254$ (IP ke Server utama/lokal)

- $\quad$ Eth 4 : many ip (IP LAN)

b. Server gateway Load balancing

- $\quad$ Eth $1: 202.52 .13 .171$ (IP dari ISP)

- $\quad$ Eth $2: 10.10 .10 .10$ (IP ke Clustering)

c. Server Utama (3 real server)

- $\quad$ Server A : 10.10.10.1

- $\quad$ Server B : 10.10 .10 .2

- $\quad$ Server C : 10.10 .10 .3

d. Database Server : 10.10 .10 .20

Dari perancangan konfigurasi load bancing diimplementasi seperti topologi jaringan pada gambar 5 .

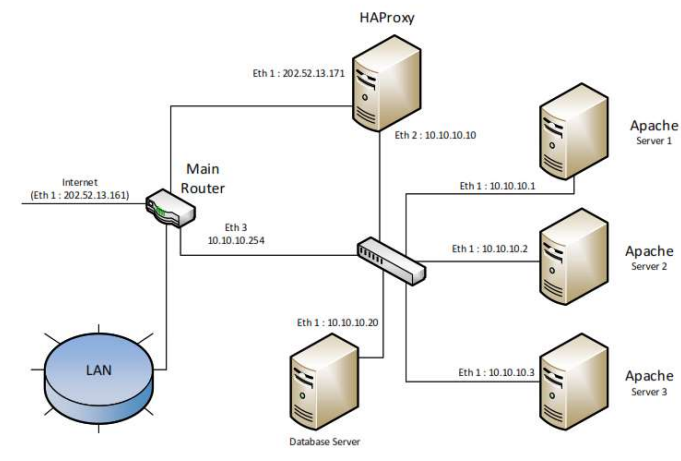

Gambar 5. Desain konfigurasi Kabel jaringan Server

\subsection{Kebutuhan Hardware dan Software}

Kebutuhan hardware dibagi 2 kategori, hardware client dan hardware server. Untuk hardware server disesuaikan dengan pengadaan hardware yang dilakukan UPT TIK Universitas Siliwangi, sedangkan client tidak memerlukan spesifikasi khusus. Untuk kebutuhan Software spesifikasi dibagi 2 kategori, software client dan software server. Untuk client hanya dibutuhkan web browser untuk akses web dan untuk server memerlukan OS unix untuk semua server, HAProxy untuk server load balance, apache dan unison untuk server utama dan MariaDB untuk database.

Spesifikasi teknis kebutuhan hardware dan Software bisa dilihat pada tabel 1 .

Tabel 1. Spesifikasi teknik kebutuhan hardware dan Software untuk implementasi

\begin{tabular}{|c|c|c|}
\hline \multirow{2}{*}{\multicolumn{3}{|c|}{\begin{tabular}{|l|l|} 
No Deskripsi \\
Kebutuhan Client
\end{tabular}}} \\
\hline & & \\
\hline & Hardware & \\
\hline \multirow[t]{2}{*}{1} & Spesifikasi teknis PC & Standart \\
\hline & Software & \\
\hline 1 & OS & All OS \\
\hline & Web Browser & \begin{tabular}{|l|} 
Support HTML 5 \\
\end{tabular} \\
\hline \multicolumn{3}{|c|}{ Kebutuhan Server } \\
\hline & Hardware & \\
\hline 1 & Load Balance & HP Proliant DL360 G9 \\
\hline 2 & Web Server & HP Prolisn DL180 G9 \\
\hline \multirow[t]{2}{*}{3} & Database Server & HP Prolisn DL180 G9 \\
\hline & Software & \\
\hline 1 & OS & Centos \\
\hline 2 & Load Balancing & HAProxy \\
\hline 3 & Web Server & Apache \\
\hline 4 & Database & MariaDB \\
\hline
\end{tabular}

\subsection{Instalasi Load bancing}

Tahapan pertama untuk konfigurasi load balancing yaitu pembaruan repositori pada server dengan perintah \#yum update. Setelah proses update selesai lakukan instal paket haproxy dengan perintah \#yum install haproxy kemudian dilanjutkan dengan konfigurasi haproxy yang terletak pada file /etc/haproxy/haproxy.cfg file konfigurasi haproxy dapat dilihat pada gambar 6 .

Pada file konfigurasi gambar 6, masukan IP Address public untuk balancer yaitu 202.52.13.171 kemudian masukan IP Address masing - masing node cluster dan disertakan angka 80 yang menandakan port untuk protokol http. Langkah selanjutnya membuka firewall pada server balancer untuk services http dan port $80 /$ tcp dengan menggunakan perintah seperti pada gambar 6 dan gambar 7.

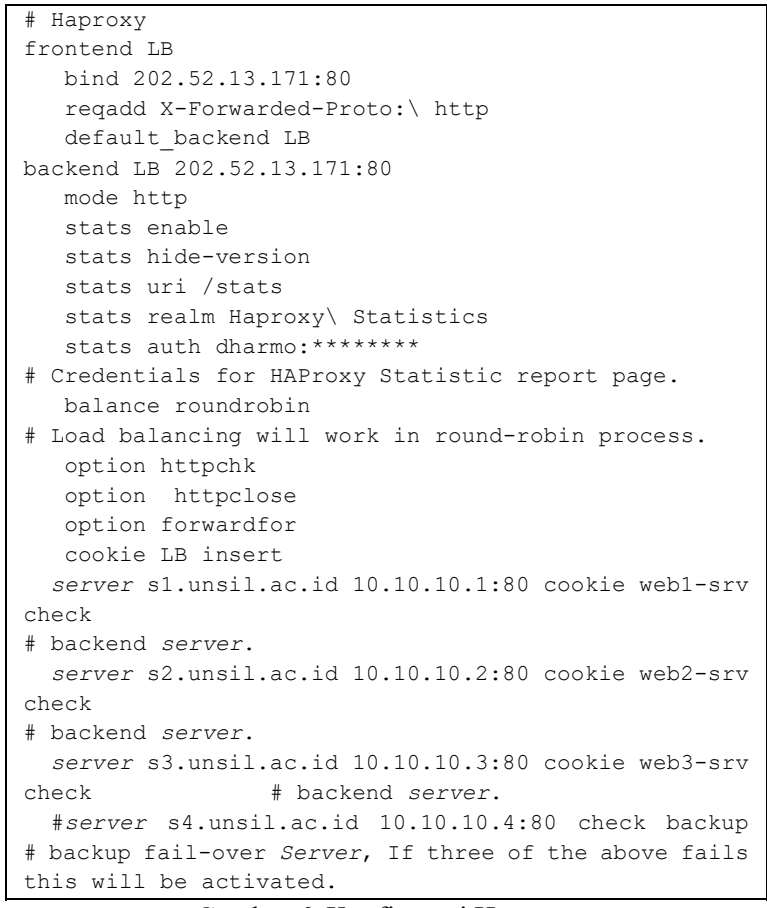

Gambar 6. Konfigurasi Haproxy 


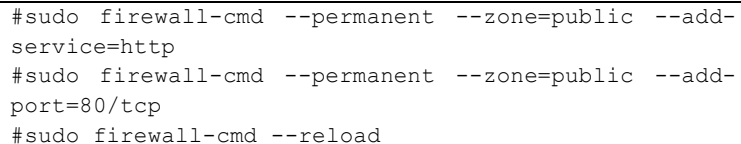

Gambar 7. Konfigurasi Firewall

Tahap selanjutnya adalah instalasi webserver yang terdiri dari paket httpd php dan php-mysql dengan perintah \# yum install httpd php php-mysql. Setelah proses selesai, buka firewall untuk port dan services pada setiap server node yang digunakan oleh webserver (gambar 8). Kemudian restart services firewall dan lakukan pengecekan dengan membuka IP Address Node cluster pada browser.

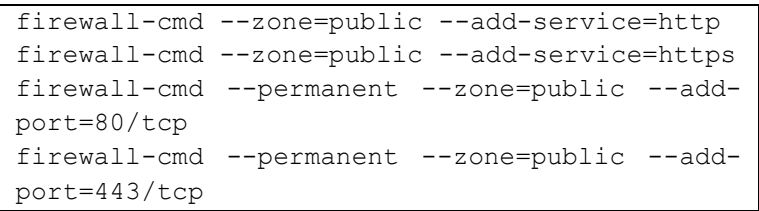

Gambar 8. Perintah membuka firewall untuk services http, https, port 80 ,dan port 443 .

\subsection{Pengujian}

Pengujian ini dilakukan untuk mengetahui apakah balancer melakukan pembagian beban secara baik. Penulis menggunakan fitur Statistic Report dari Haproxy untuk mengetahui current connection pada setiap node cluster. Dengan menggunakan Apache Bench sebagai pengirim request, dengan beban request 150/detik. Kemudian untuk melihat pembagian beban request peneliti melakukan refresh secara berkala terhadap Statistics Report. Hasil pengujian fungsi load balancer dapat dilihat pada Gambar 9 sampai dengan Gambar 14 dan pada tabel 2.

Tabel 2. Rekap Hasil Pengujian Pembagian Beban

\begin{tabular}{|c|c|c|c|c|}
\hline Pengujian ke & Node 1 & Node 2 & Node 3 & Total request \\
\hline 1 & 58 & 56 & 55 & 169 \\
\hline 2 & 47 & 48 & 46 & 141 \\
\hline 3 & 69 & 70 & 68 & 207 \\
\hline 4 & 58 & 57 & 55 & 170 \\
\hline
\end{tabular}

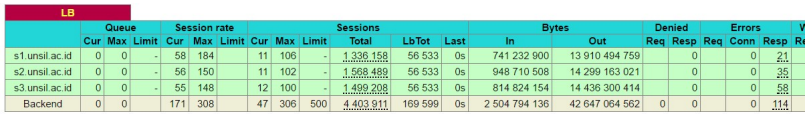

Gambar 9. Hasil Pengujian Pembagian Beban (1)

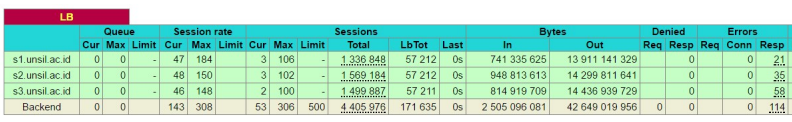

Gambar 10. Hasil Pengujian Pembagian Beban (2)

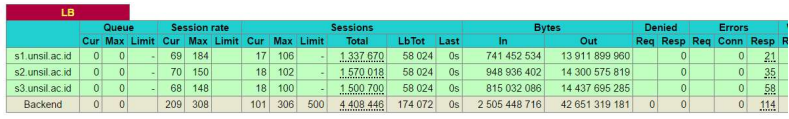

Gambar 11. Hasil Pengujian Pembagian Beban (3)

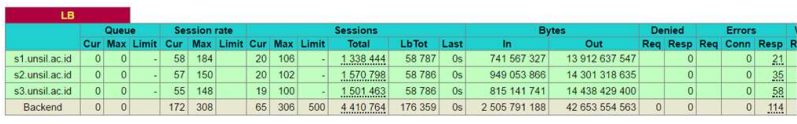

Gambar 12. Hasil Pengujian Pembagian Beban (4)
Dari empat kali pengujian fungsi load balancing pada Hproxy yang dipasang pada server Simak Universitas Siliwangi, didapat hasil yang seimbang dalam membagi request terhadap 3 server yang dipasang.

Fungsi lain yang dimiliki Hproxy selain Load balancing yaitu fungsi failover, fungsi failover berfungsi untuk membelokkan request jika ada 1 (satu) atau lebih server yang fungsi http/https nya mati, request keserver yang tidak berfungsi akan dibelokkan ke server lain yang ada.

Untuk menguji fungsi failover ini bekerja dengan baik penulis akan mematikan node 1 dan node 3 . Kemudian akan dicoba mengakses halaman sistem akademik dengan alamat http://simak.unsil.ac.id. seperti pada gambar 13.

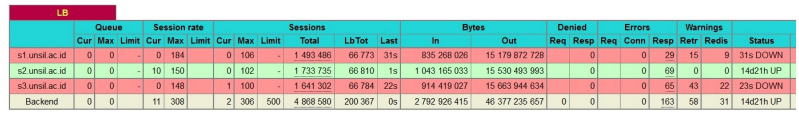

Gambar 13. Pengujian Failover

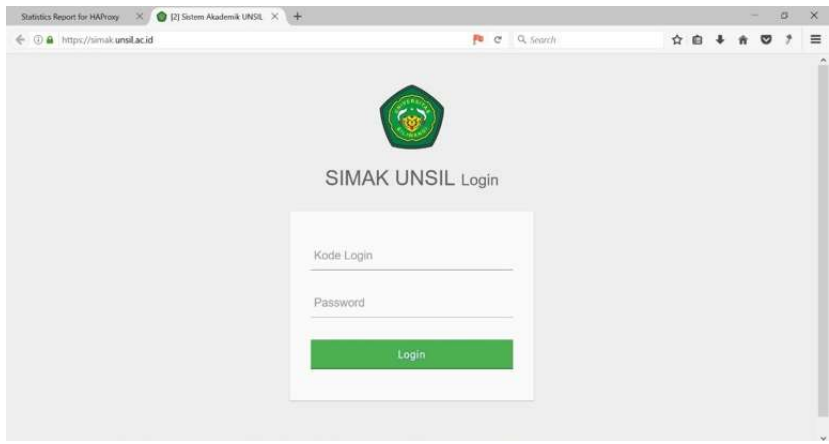

Gambar 14. Pengujian Akses SIMAK

Pada gambar 13 terlihat bahwa 2 server sudah dalam keadaan mati ditandai dengan warna merah pada baris node 1 dan node 3 . Kemudian pada gambar 14 dicoba akses halaman http://simak.unsil.ac.id dengan web browser dan server node 2 berhasil merespon.

Pengujian dilakukan untuk mengetahui waktu respon web server terhadap request yang datang. Dalam melakukan pengujian digunakan perangkat lunak Apache Bench. Pada proses pengujian digunakan 10.000 request baik pada server tunggal dengan IP Address 202.52.13.172 maupun pada server cluster dengan IP Address Balancer 202.52.13.171.

Hasil pengujian server cluster dapat dilihat pada Gambar 15 dan Gambar 16 sedangkan pengujian pada server tunggal dapat dilihat pada Gambar 17 dan Gambar 18. Dari hasil pengujian didapatkan angka 11,909 ms untuk rata - rata response time dari web server tunggal. Sedangkan untuk web server cluster diperoleh angka 5,447 ms untuk rata - rata response time nya. Server cluster bisa melayani request 2 kali lebih cepat dibanding dengan server tunggal.

Kemudian selain waktu response pada pengujian ini didapatkan juga failed request atau permintaan yang gagal dilayani baik oleh server tunggal mupun server cluster. Pada server tunggal angka failed request sebesar 2813 yang berarti sebanyak itu request tidak berhasil dilayani sedangkan pada server cluster angka yang diperoleh adalah 0 berarti semua request berhasil dilayani.

Dalam melayani request yang datang, server cluster dipengaruhi oleh keberadaan balancer dan 3 buah node cluster didalamnya. Balancer memiliki algoritma penjadwalan roundrobin sehingga dapat meneruskan request yang datang kepada balancer dibagi 
kedalam 3 buah node cluster secara sama rata sehingga kerja server tidak bertumpu pada satu server saja tapi request yang datang akan dilayani oleh 3 node cluster. Sehingga waktu response akan jauh lebih cepat.

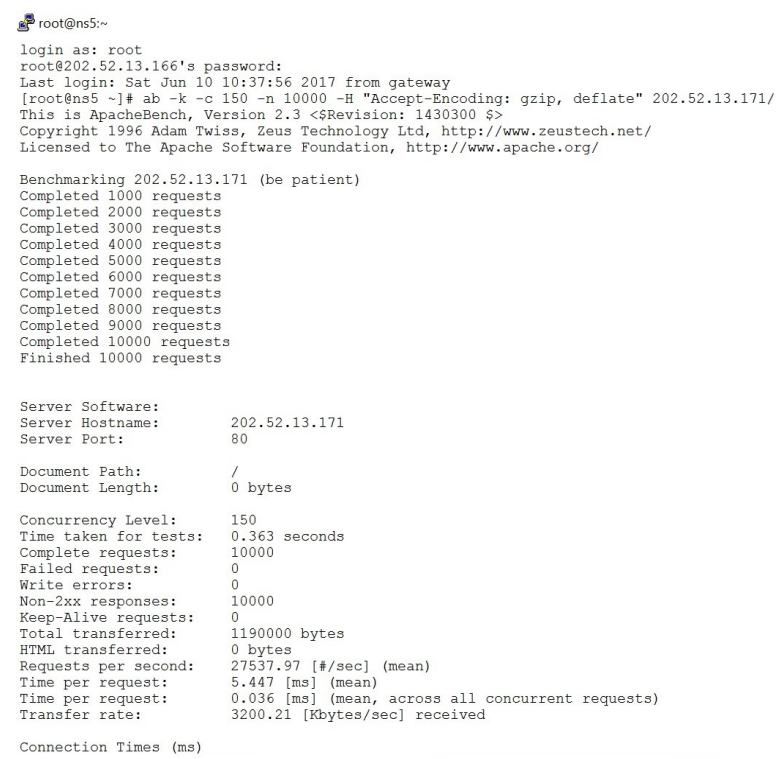

Gambar 15 Hasil Pengujian Server Cluster (1)

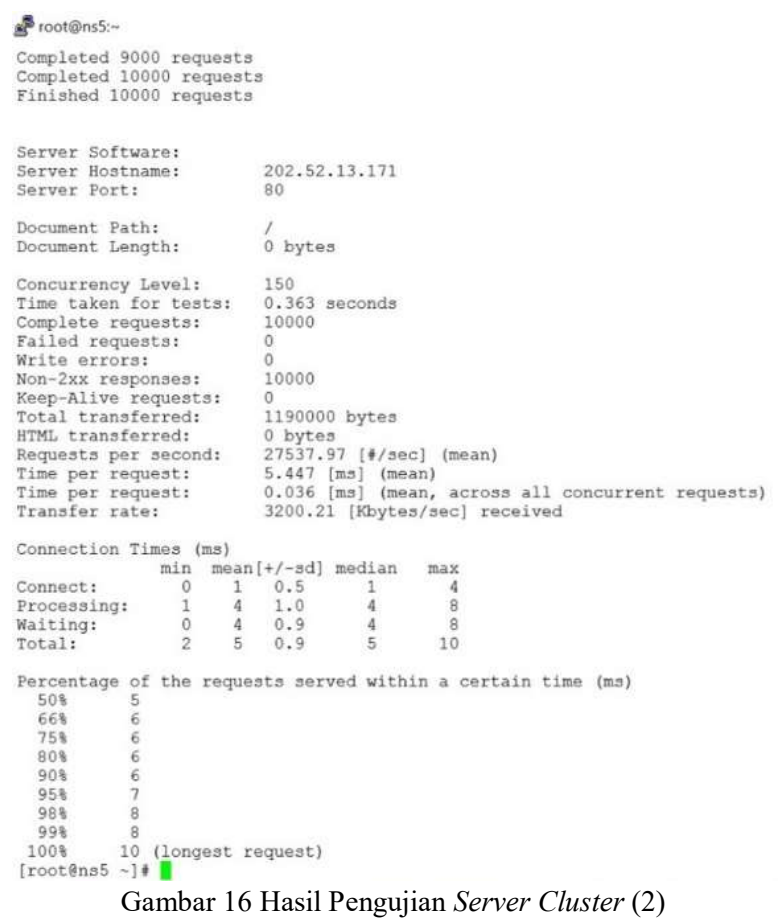

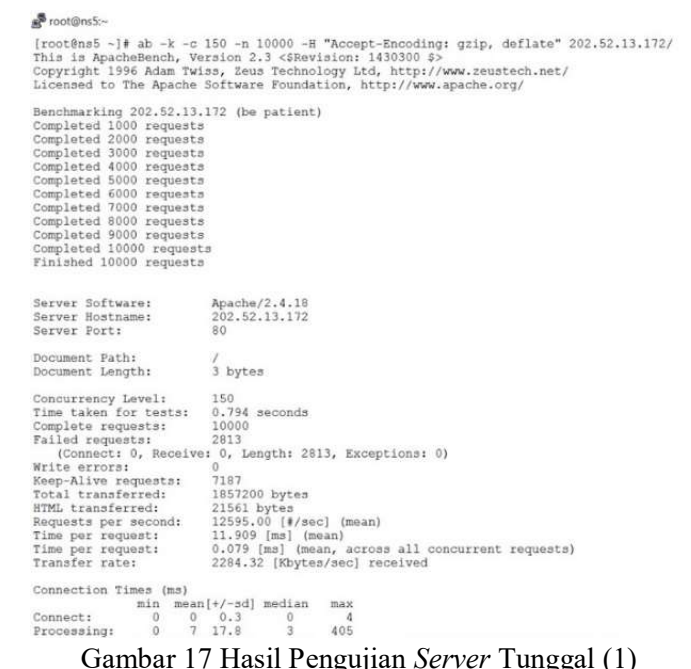

s root@ns:-

Completed 9000 requests Completed 10000 request

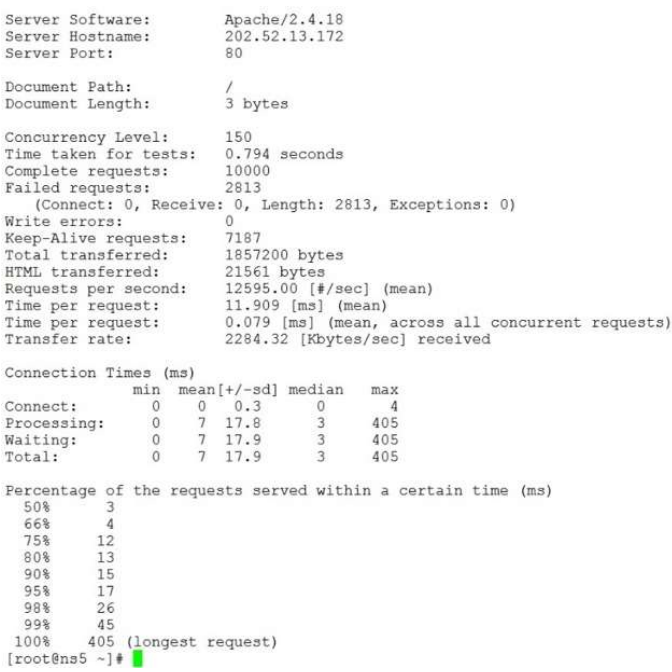

Gambar 18 Hasil Pengujian Server Tunggal (2)

Langkah selanjutnya yaitu mengatur sinkronisasi file pada semua node cluster. Terlebih dahulu install ntp server untuk proses sinkronisasi ini perintah yang digunakan \#yum install ntp. Setelah itu lakukan installasi unison dan terlebih dahulu yang dapat diunduh packet unison pada link http://www.seas.upenn.edu/ bcpierce/unison//download/releases /unison-2.48.3/unison-2.48.3.tar.gz. Tahap selanjutnya konfigurasi ssh server pada setiap node cluster supaya server dapat saling berhubungan dengan protocol ssh tanpa harus menggunakan password. Setelah melakukan instalasi ssh dengan perintah \#yum install ssh kemudian buat certificate sebagai pengganti password ssh dan berikan chmod 600. Sampai tahap konfigurasi sudah selesai tapi untuk menjalankan sinkronisasi file secara otomatis kita harus mengatur supaya script yang terdapat pada Listing 1 dijalankan cron setiap menit pada node 1 dan script pada Listing 2 dijalankan oleh cron pada node dua.

Listing 1 Script Sinkronisasi file node 1. 
unison -batch /var/www/html/simak/us-unsil/foto $\mathrm{ssh}$ ///10.10.10.2//var/www/html/simak/us-unsil/foto unison -batch /var/www/html/simak/us-unsil/imgwisuda ssh://10.10.10.2//var/www/html/simak/usunsil/imgwisuda

Listing 2 Script Sinkronisasi file node 2.

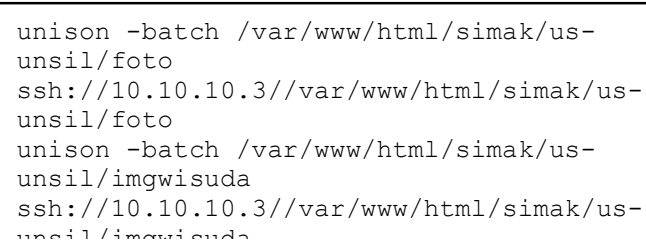

IP Address disesuaikan dengan node cluster tujuan yang akan melakukan singkoronisasi. Perlu diketahui juga unison ini melakukan sinkronisasi dua arah. Sehingga kita tidak harus mengkonfigurasi 2 kali pada salah satu server node cluster.

Langkah selanjutnya peneliti melakukan pengujian terhadap implementasi sinkronisasi file terhadap 3 server node cluster. Dalam pengujian ini penulis akan membuat sebuah file pada salah satu server node cluster yaitu node 1 kemudian akan di cek di node 2 dan node 3 cluster apakah file yang diupload ada pada kedua server tersebut. Kemudian akan dicoba menambahkan file dari server lainnya, yaitu node 3 untuk membuktikan bahwa proses sinkronisasi terjadi 2 arah sesuai dengan desain. Hasil pengujian dapat dilihat pada Gambar 19 sampai dengan Gambar 22.

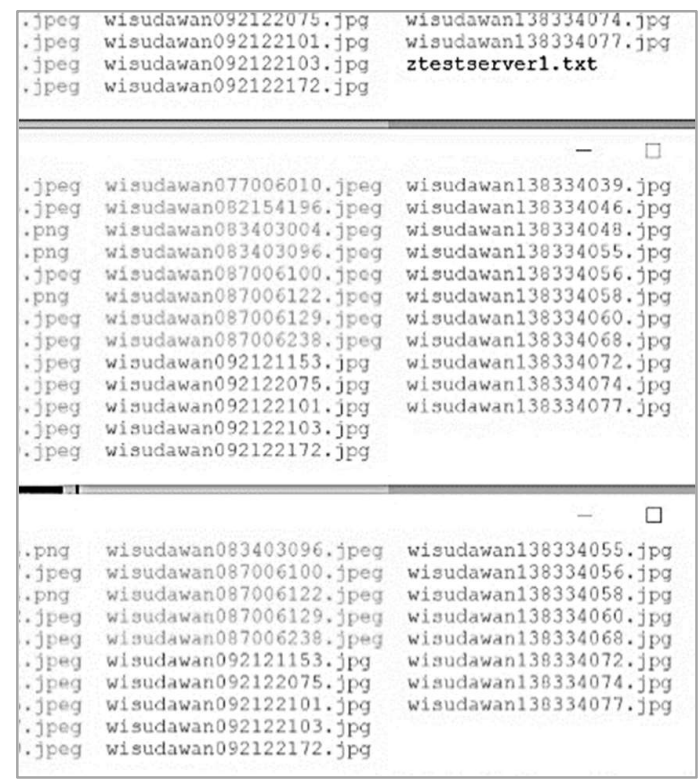

Gambar 19 Pengujian Sinkronisasi File (1)

Pada Gambar 19 dibuat sebuah file pada node 1 dengan nama file ztestserver1.txt kemudian selanjutnya ujicoba apakah file tersebut ada pada node 2 dan node 3. Gambar 20 membuktikan bahwa file tersebut masuk ke node 2 dan node 3 dengan proses sinkronisasi menggunakan unison. Kemudian pada Gambar 21 dibuat sebuah file pada node cluster 3 dengan nama ztestserver3.txt dan file yang dibuat telah berhasil sinkron pada node 2 dan 3 (Gambar 22).

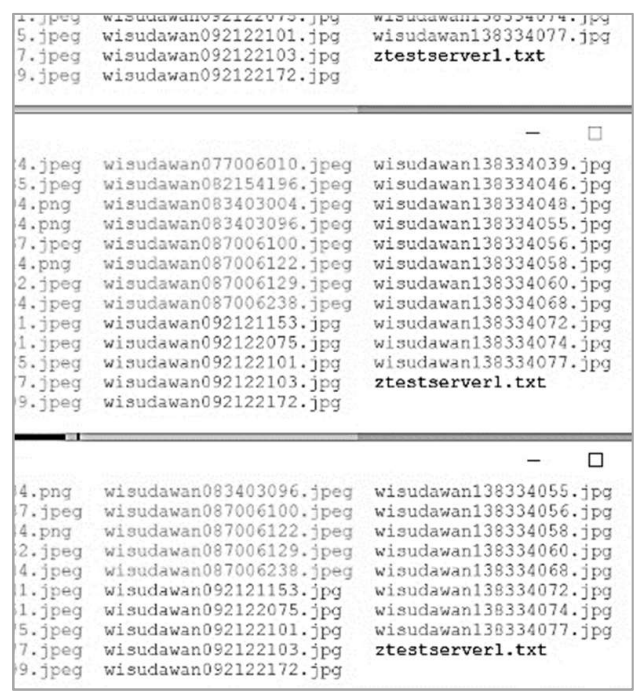

Gambar 20 Pengujian Sinkronisasi File (2)

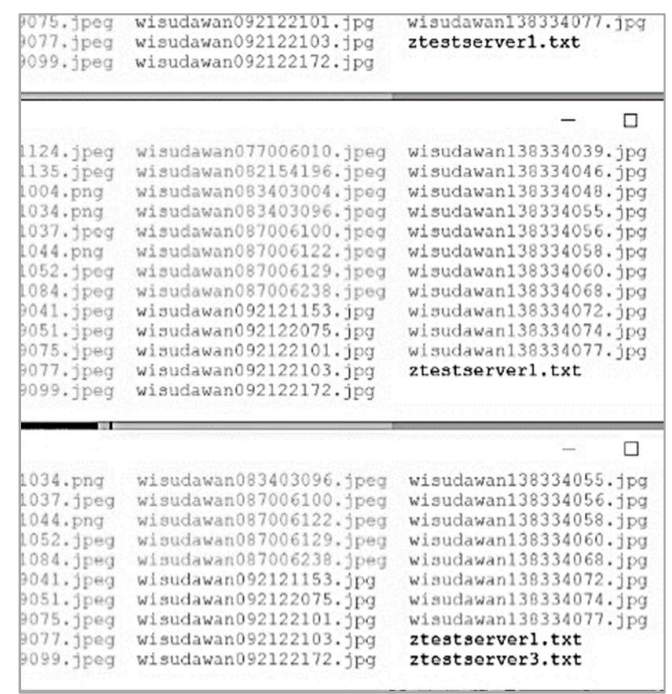

Gambar 21 Pengujian Sinkronisasi File (3)

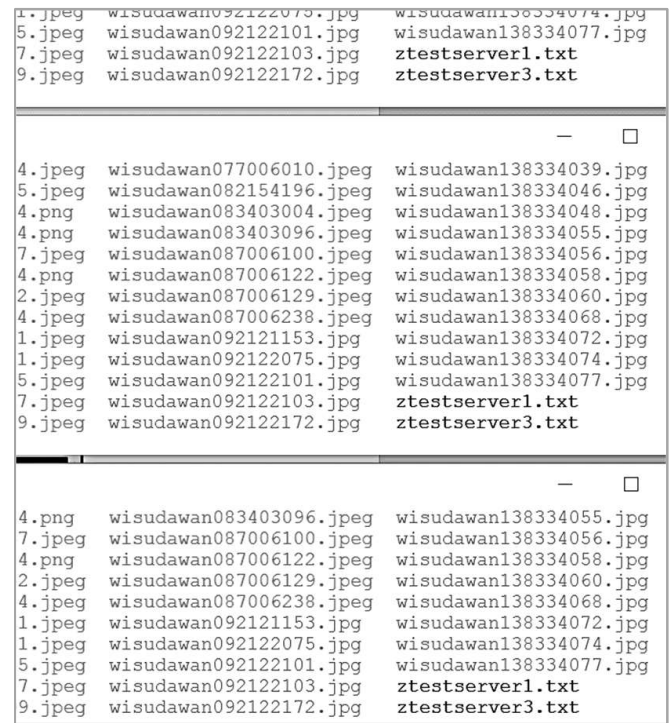

Gambar 22 Pengujian Sinkronisasi File (4) 


\section{KESIMPULAN}

Berdasarkan penelitian yang telah dilakukan maka didapatkan kesimpulan yaitu:

1. Sistem load balancing dapat bekerja dengan baik ketika request datang dari client telah berhasil didistribusikan balancer secara merata kepada setiap node cluster. Sehingga server tidak mengalami overload dan kemampuan web server bisa melayani 10.000 request dengan tidak mengalami error request.

2. Penerapan sinkronisasi file bekerja dengan baik dimana file yang diupload pada node 1 akan disinkron ke setiap node 2 dan node 3 pada cluster, begitu juga sebaliknya karena sinkronisasi file ini bersifat dua arah.

3. Dengan implementasi clustering server dapat meningkatkan respon time web server dan meningkatkan jumlah current connection yang dapat dilayani oleh server.

Adapun Saran bagi penelitian selanjutnya yaitu :

1. Penerapan clustering web server ini bisa di tambahkan dengan clustering database server. Untuk mengimbangi performance dari web server.

2. Untuk balancer bisa dibuat menjadi 2 buah salah satunya difungsikan sebagai balancer cadangan. Sehingga ketersediaan server akan lebih baik.

3. Pada proses singkronisasi file akan lebih baik bila prosesnya bisa realtime sehingga pengguna tidak harus menunggu.

4. Selain proses sinkronisasi file untuk penyimpanan file bisa dengan menambahkan NAS (Network Attached Storage).

\section{UCAPAN TERIMA KASIH}

Terimakasih kepada kemenristekdikti yang telah mendanai penelitian dosen pemula pada periode tahun 2017.

\section{DAFTAR PUSTAKA}

[1] G. H. Megan., Design and Implementation of Server Virtualization in Thiess Contractors Indonesia, Yogyakarta: Universitas Gajah Mada, 2010.

[2] [Online]. Available: www.httpd.apache.org.

[3] A. B. M. Moniruzzaman, M. Waliullah dan M. S. Rahman, "A High Availability Clusters Model Combined with Load Balancing and Shared Storage Technologies for Web Servers," dalam International Journal of Grid Distribution Computing, 2015.

[4] K. Kaur dan A. K. Rai, "A Comparative Analysis: Grid, Cluster and Cloud Computing," dalam International Journal of Advanced Research in Computer and Communication Engineering, 2014.

[5] M. Rosalia, R. Munadi dan R. Mayasari, "IMPLEMENTASI HIGH AVAILABILITY SERVER MENGGUNAKAN METODE LOAD BALANCING DAN FAILOVER PADA VIRTUAL WEB SERVER CLUSTER," dalam e-Proceeding of Engineering, 2016.

[6] Sirajuddin, A. Affandi dan E. Setijadi, "Rancang Bangun Server Learning Management System Menggunakan Load Balancer dan Reverse Proxy," JURNAL TEKNIK ITS, pp. 50-52, 2012.

[7] I. Sofana, Membangun Jaringan Komputer, Bandung: Informatika, 2008.
[8] Apache, "Apache," [Online]. Available: www.httpd.apache.org/docs $/ 2.2 / \mathrm{misc} /$ perf-tuning.html. [Diakses 5 March 2017]

[9] S. Eludiora, O. Abiona, G. Aderounmu, A. Oluwatope, C. Onime dan L. Kehinde, "A Load Balancing Policy for Distributed Web Service," dalam International Journal of Sciences, Vol. 3 No. 8 , Hal. 645-654., 2010.

[10] H. Kameda, J. Li, C. Kim dan Y. Zhang, "Optimal Load Balancing in Distributed Computer Systems," Springer, 2012.

[11] HaProxy, "HaProxy," [Online]. Available: https://haproxy.org/\#docs/. [Diakses 20 March 2017].

[12] R. Froom, B. Sivasubramanian dan E. Frahim, "Implementing Cisco IP Switched Networks (SWITCH) Foundation Learning Guide: Foundation learning for SWITCH 642-813," Cisco Press, 2010.

[13] cisco, "ciscozine.com," 29 January 2009. [Online]. Available: http://www.ciscozine.com/the-ppdioo-network-lifecycle/. [Diakses 30 March 2017].

[14] C. Networking, “Cisco Networking," [Online]. Available: http://www.dummies.com/programming/networking/cisco/cisconetworking-design-and-layout-methodology-overview. [Diakses 20 March 2017].

\section{BIODATA PENULIS}

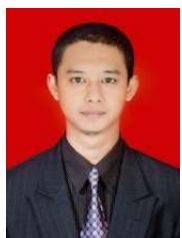

Alam Rahmatulloh, S.T., M.T. saat ini menjadi dosen Teknik Informatika Fakultas Teknik Universitas Siliwangi Tasikmalaya, serta praktisi aktif dalam bidang informatika, web programming, software security, multimedia. Selain pengajar, berperan aktif bidang IT di Universitas Siliwangi Tasikmalaya.

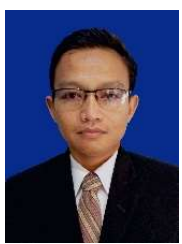

Firmansyah Maulana Sugiartana Nursuwars, S.T., M.Kom merupakan seorang dosen teknik informatika Fakultas Teknik Universitas Siliwangi Tasikmalaya, praktisi dan aktif dalam penelitian di bidang elekktronika, aplikasi mikrokontroller, robotika, IoT, pemograman komputer dan jaringan komputer. Selain sebagai pengajar juga pernah menjabat sebagai penanggung jawab teknis bagian jaringan di UPT.TIK Universitas Siliwangi, dan sekarang menjabat sebagai sekertaris jurusan teknik elektro fakultas teknik Universitas Siliwangi 